\title{
Effect of Rooting Media, Cutting Types and Watering Frequency on Dry Matter Production of Long Pepper (Piper cappense) at Jimma
}

\author{
Gebreslassie Hailu and Mohammedsani Zakir* \\ Ethiopian Institute of Agricultural Research; Jimma Agricultural Research Center, Jimma Ethiopia
}

*Corresponding Authors: Mohammedsani Zakir, Ethiopian Institute of Agricultural Research; Jimma Agricultural Research Center, Jimma Ethiopia

\begin{abstract}
Long pepper cuttings are traditionally planted in a trench \& covered with plastic sheet to get large number of transplantable seedlings. But the success of the transplant is often low hence; it is common to retain cuttings for more than a year to synchronize their stage of transplanting with start of main rainy season. This requires extra costs for nursery operation \& maintenance that needs further research focus to fill the gap alleviated by identifying best growing media, suitable type of cutting type \& identifying appropriate watering frequency. The present study was conducted at Jimma Agricultural Research Center (JARC) to investigate the influence of rooting media, cutting types and watering frequency on dry matter production of long pepper cuttings. Four types of media, composed of sub soil(ss), top soil(ts), farmyard manure(fym) and fine sand with the following proportion, 2top soil +1 farmyard manure +2 fine sand recommended for coffee cutting , 6top soil +3 farmyard manure +2 fine sand recommended for coffee nursery, $1 / 3^{\text {rd }}$ ss upper +2 top soil +1 farmyard manure + lfine sand recommended for tea media and 2 top soil + lfarmyard manure + lfine sand recommended for coffee nursery, three level of cutting type soft wood (sw), semi hard wood(shw) and hard wood ( $h w)$ and four level of watering frequency were combined in split plot design with three replications, where four watering frequency levels were assigned to main plots, four media type levels were assigned to sub plot and three types of cutting (soft wood, semi hard wood and hard wood) levels were assigned to sub-sub plot were combined with factorial arrangement $(4 \times 4 \times 3)$ with 48 treatments. Data was collected for root and shoot dry matter production after six months of planting. The analysis of variance for average dry shoot weight was significantly influenced by watering frequency, rooting media and cutting type. The main effect of watering frequency, rooting media, the interaction effect of watering frequency with rooting media, watering frequency with cutting type and media with cutting type, the three way interaction effect of watering frequency, rooting media and cutting type were very highly significant $(P<0.001)$ difference. Attention should also be given in selecting the cutting type and position on the stock plant while preparing the cuttings.
\end{abstract}

Keywords: Dry matter, wood, watering, hard wood and frequency

\section{INTRODUCTION}

Long pepper derived from two species of piper (piper officinarum Decandolle (more)(chavica officinarum, Miqual). Producing the java long pepper, and piper longum, Linne (more) (chavaicaRoxburghii, Miquel) producing the India long pepper. The long peppar of India and Indonesia comes from slender climber that has sparser looking foliage than piper nigram. The most noticeable difference between the two is that the fruit of Indian long pepper (P. longum) are smaller and less pungent than those java long peppers (Piper retrofractum). This spice crop is called as Long pepper because the fruit are long cylindrical spikes $5 \mathrm{~mm}$ in diameter and 2.5 to $4 \mathrm{~cm}$ in length. Long pepper (piper species) and black pepper is a perennial shrub belongs to the family piperaceae. Long pepper (Piper cappense) is indigenous spice crop"Timiz". Long paper, is similar to korarima (Afromamum korarima) and grows wild and semi wild under the natural forests of the South and Southwestern parts of Ethiopia. It grows best in forest areas of the mid to high altitudes in Keficho and Dawuro zones of the southern region (mainly around Bonga, Wushwush and Waka areas) Jimma and areas that have comparable climatic conditions to Jimma are suitable for long pepper production. Long pepper and korarima, as a natural forest crops; require 50-63\% Shade level.

The commercial part of Long pepper is widely used by every Ethiopian in the preparation of 'Wot' and serves as ingredient for other spice ingredients. In Ethiopia this spice is both the exotic species (by introducing the dried spike) and the locally produced long pepper spikes, apart from pepper (p. 
nigrum L.) are being utilized for seasoning and provide oil which to a certain extent is used as an aromatic in the drinks industry and for medicine. In Ethiopia, field surveys have shown both the utilized and the wild species of long paper found growing under story the natural forest area of Ethiopia.

The crop is a short shrub that can be disturbed if appropriate cultural practices are not applied. The field where long pepper should be planted during the rainy seasons since much undergrowth is expected. When the dry season commence mulching and sometimes watering advisable. This spice is growing under the shade of natural forest and sometimes when the shade become very dense and this time it needs to remove some of the branches to let in light inside for effective flowering, pollination, fruiting, and maturity. Long pepper grows under natural forest but from experience, this plant has the tendency to moves towards the open areas or margin of the forest or shade of the forest.

Long pepper cuttings are traditionally planted in a trench and covered with plastic sheet to get large number of transplantable seedlings. However, the success of the transplant is often low hence; it is common to retain cuttings for more than a year to synchronize the transplanting time with the beginning of the rainy season. This requires extra costs for nursery operation $\&$ maintenance. This can be alleviated by identifying the best growing media, suitable type of cutting type \& identifying appropriate watering frequency. However, no research work has been carried out on cutting propagation of long pepper and hence, much of the information on nursery practices and improved long pepper propagation technologies is lacking in the growing area of Ethiopia. Therefore, this study was designed to address the above-mentioned gaps.

\section{MATERIALS AND METHODES}

\subsection{Description of the Study Area}

The study was conducted at Jimma Agricultural Research Center (JARC) located $365 \mathrm{~km}$ South West of Addis Ababa, and $12 \mathrm{~km}$ away from Jimma town. The Nursery site is located at $7^{\circ} 40^{\prime} \mathrm{N}$ latitude and $36^{\circ} 47^{\prime} E$ longitudes with an altitude of 1753 meters above sea level. It situated in the tepid to cool humid-mid highlands of southwestern Ethiopia. The long-term (ten years) mean annual rainfall of the area is $1639 \mathrm{~mm}$ with a maximum and minimum air temperature $26.6{ }^{\circ} \mathrm{C}$ and $13.9^{\circ} \mathrm{C}$ respectively. According to JARC 2010 meteorology data the relative humidity of the area ranges from 35 to 95 percent.

\subsection{Experimental Treatments}

The experimental materials used in this study include, rooting media composed of top soil, sub soil, farmyard manure, Fine sand, stem cutting obtained long pepper accession among from the 1979 collection batch and Watering frequency.

\subsection{Rooting Media Proportions (Types)}

The basic media used for the preparation of the potting mixes were top soil, sub-soil, farmyard manure and fine river sand. Top soil was collected from the upper $25 \mathrm{~cm}$ layer of uncultivated land and the sub soil next to the layer of the top soil at about 30-35 cm depth was also collected from the same area. Well decomposed animal dung were collected from dairy farming privet enterprise around Jimma town, these materials were sun dried, crushed and also sieved through mesh before mixing with other media categories. Finally, four rooting media types with the following proportion $(\mathrm{v} / \mathrm{v})$ were prepare.

\subsection{Rooting Media (1-4 types)}

M1 = Top soil + Farmyard manure + Fine sand at 2:1:2 ratios recommended for coffee cutting

M2 = Top soil + Farmyard manure + Fine sand at 6:3:2 ratios recommended for coffee nursery

M3 = 1/3 Sub soil upper + Top soil +Farmyard manure + Fine sand at 2:1:1 ratio tea media

M4 = Top soil + Farmyard manure + Fine sand at 2:1:1 ratios recommended for coffee nursery

\subsection{Preparation of Cutting Types}

Long pepper already established in the clone garden of Tepi Agricultural Research Center; vertically grow orthotropic shoots was used as a source of stem cutting, uniform and healthy cuttings with 2-4 
nodes were harvested early in the morning when the shoot and the leaves are turgid from the soft wood (upper part of the shoot), semi hard wood (middle part of the shoot) and hard wood (nearer to the main stem) were taken using sharp and sanitized pruning shear with alcohol. The cuttings were placed immediately in the plastic bug to prevent dehydration and then transported to the actual propagation site where the whole operation carried out under shaded condition to provide protection against sun light.

Double node cutting of soft wood, semi hard wood and hard wood cutting were prepared by cutting the shoot just above each node and the woody and young parts from the lower and upper ends of the shoot, respectively. The leaves on both types of cutting were trimmed totally to reduce the rate of transpiration. Slant cut at the base of each cutting were made before setting them in the rooting media. To maintain internal turgidity, all the cuttings were kept in a plastic bug. Finally, inserted to a depth of 3-4 cm into the potted media in February 2012 and watered up to field capacity. The polythene sheet buried along the edges of the bed to provide humidified environment for the cuttings.

\subsection{Watering Frequency}

The quantity of water applied to a plot at a time (per irrigation) was Equivalent to the amount required to replenish or maintain the moisture content of the growth medium at field capacity. Entrance of water into adjacent plots upon irrigating a plot was controlled by carful application using fine-holed standard watering can. Water from external sources, particularly rainfall was prevented by white transparent plastic film spread over wooden poles and string to cover the main plot, the plastic film was closed all the time except during watering hours of the day.

\subsection{Propagator Structure}

Eucalyptus wood, elephant grass and 30 micron thick white plastic sheet was used to contract the propagator. Raised nursery beds with $1.2 \mathrm{~m}$ width $\mathrm{x} 10 \mathrm{~m}$ length were prepared to arrange the treatments. Then, simple and inexpensive non-mist propagator was made from wooden frame (eucalyptus tree post). The frame was covered with 30-micron thick white translucent plastic sheet.

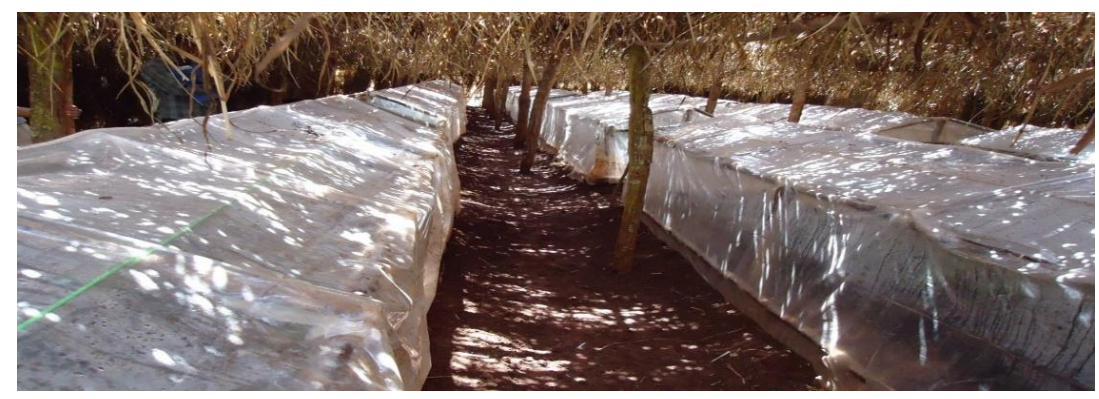

Figure1. Propagator structure framework

Artificial shade supported with wooden poles were made at a height of 2 meter above the ground level and covered with elephant grass to provide approximately 70 to $75 \%$ shade (Behailu et al., 2006), and both sides of the propagator was also protected with the elephant grass to avoid direct sunlight.

\subsection{Experimental Design and Treatment Layout/Arrangement}

The Experiment was conducted in the nursery at Melko (JARC) using stem cutting of long pepper in split plot design with 3 replications, where Four watering frequency levels were assigned to main plots, four media type levels were assigned to sub plot and three types of cutting (Soft wood, semi hard wood and hard wood) levels were assigned to sub- sub plot were combined with factorial arrangement ( $4 \times 4 \times 3)$ with 48 treatments (Table 1). Each treatment contains 12 cuttings and 1728 cuttings were used for the experiment. The cutting was inserted directly in the media filled in $16 \mathrm{~cm}$ wide and $25 \mathrm{~cm}$ long black polyethylene bags and randomly assigned in the propagator with in main plot with two rows and $10 \mathrm{~cm}$ spacing between treatments.

Table1. Details of Treatment Combination with in main plot

\begin{tabular}{|l|l|l|l|}
\hline $\begin{array}{l}\text { Treatment } \\
\text { No }\end{array}$ & Watering Frequency & Media & Cutting types \\
\hline 1. & Every week & TS : FYM $:$ FS $(2: 1: 2)$ & SW \\
\hline 2. & Every week & TS : FYM $:$ FS $(2: 1: 2)$ & SHW \\
\hline 3. & Every week & TS : FYM : FS $(2: 1: 2)$ & HW \\
\hline
\end{tabular}


Effect of Rooting Media, Cutting Types and Watering Frequency on Dry Matter Production of Long Pepper (Piper cappense) at Jimma

\begin{tabular}{|l|l|l|l|}
\hline \hline 4. & Every week & TS: FYM : FS $(6: 3: 2)$ & SW \\
\hline 5. & Every week & TS: FYM : FS $(6: 3: 2)$ & SHW \\
\hline 6. & Every week & TS: FYM : FS $(6: 3: 2)$ & HW \\
\hline 7. & Every week & $1 / 3$ SS+TS: FYM $:$ FS $(2: 1: 1)$ & SW \\
\hline 8. & Every week & $1 / 3$ SS+TS: FYM : FS $(2: 1: 1$ & SHW \\
\hline 9. & Every week & $1 / 3$ SS+TS: FYM : FS $(2: 1: 1$ & HW \\
\hline 10. & Every week & TS : FYM : FS $(2: 1: 2)$ & SW \\
\hline 11. & Every week & TS : FYM : FS $(2: 1: 2)$ & SHW \\
\hline 12. & Every week & TS : FYM : FS $(2: 1: 2)$ & HW \\
\hline
\end{tabular}

Media; TS= top soil, FYM= farmyard manure, FS= fine sand. Cutting type; SW=soft wood, SHW=semi hard wood, HW=hard wood

\subsection{After Planting Care}

To maintain the required level of moisture, temperature and relative humidity, water application manually using 10-liter capacity plastic watering cane was done depending upon the time of watering Frequency (every Week, every Two Weeks, every Three Weeks and every Month) was carried out accordingly by opening and closing back the polyethylene sheet. A daily minimum and maximum temperature inside the propagator were recorded using thermometer and the range was $22-23^{\circ} \mathrm{C}, 20$ $21^{\circ} \mathrm{C}, 21-22^{\circ} \mathrm{C}$ and $29^{\circ} \mathrm{C}$ under watering interval every week, every two weeks, every three weeks and every Month respectively. The relative humidity $(\mathrm{RH})$ inside the propagator was also recorded daily and the average was $66-70 \%, 80-81 \%, 81-83 \%$ and $87 \%$ watering interval every week, every two weeks, every three weeks and every four weeks respectively.

\subsection{Data Collection}

Destructive data were collected 185 days after planting. Rooting percent was determined based on all survived cuttings per plot and the average was taken. Five selected sample cutting from each plot were considered and separated in to root and shoot part and evaluated for the different parameters. The parameters measured and the methods used each were presented as follows.

\subsection{Soil Analysis}

Prior to the nursery experiment, the soil was sampled from each rooting media and prepared before planting the cuttings and analysed for the physical and chemical properties. The analysis was determined in the laboratory using the procedure outlined by Sahlemedhin and Taye (2000). The analysis was carried out at JARC soil laboratory (Table 2).

Table2. physical and chemical properties of deferent rooting media used in the present study

\begin{tabular}{|c|c|c|c|c|c|c|c|}
\hline \multirow[t]{2}{*}{ Rooting media } & \multicolumn{6}{|c|}{ Chemical properties } & \multirow{2}{*}{$\begin{array}{l}\text { Physical properties } \\
\text { Bulk density }\left(\mathrm{g} / \mathrm{cm}^{3}\right)\end{array}$} \\
\hline & $\begin{array}{l}\mathrm{P}^{\mathrm{H}} \\
\text { water(1:2.5) }\end{array}$ & $\begin{array}{l}\mathrm{P} \\
(\mathrm{ppm})\end{array}$ & $\% \mathrm{OC}$ & $\% \mathrm{OM}$ & $\% \mathrm{~N}$ & $\begin{array}{l}\text { Available } \\
\text { K(Meq } \\
\text { k/100 }\end{array}$ & \\
\hline $\begin{array}{l}\text { TS : FYM : FS } \\
(2: 1: 2)\end{array}$ & 5.8 & 90.31 & 4.10 & 7.06 & 0.27 & 2.69 & 1.48 \\
\hline $\begin{array}{l}\text { TS : FYM : FS } \\
(6: 3: 2)\end{array}$ & 5.67 & 153.95 & 5.29 & 9.12 & 0.41 & 3.32 & 1.44 \\
\hline $\begin{array}{l}\text { TS : FYM : FS } \\
(2: 1: 1)\end{array}$ & 5.6 & 153.95 & 5.06 & 8.73 & 0.33 & 3.32 & 1.49 \\
\hline FYM & 6.44 & 441.62 & 23.96 & 41.30 & 0.52 & 11.64 & 1.54 \\
\hline Top soil(TS) & 5.2 & 3.11 & 3.93 & 6.77 & 0.25 & 1.41 & 1.36 \\
\hline Sub soil(SS) & 5.3 & 13.06 & 2.68 & 4.62 & 0.21 & 1.53 & 1.33 \\
\hline Fine Sand(FS) & 5.74 & 15.43 & 0.75 & 1.30 & 0.02 & 0.56 & 1.64 \\
\hline
\end{tabular}

$\mathrm{OC}=$ organic carbon, $\mathrm{OM}=$ organic matter, $\mathrm{P}=\mathrm{Phosphorus,} \mathrm{N}=$ nitrogen, $\mathrm{K}=\mathrm{Potassium}$

\subsection{Physical Properties (Before Planting)}

Texture: media texture was determined by the modified Bouyucous Hydrometer method

Bulk density $(\mathrm{g} / \mathrm{ml})$ : mass of dried media $(\mathrm{g}) /$ volume of dried media $(\mathrm{ml})$ was calculate and taken for analysis. 
Water holding capacity(\%): it was calculated using the following formula

WHC $=$ weight water in the saturated media $(\mathrm{g}) \times 100$

Weight of saturated media(g)

\subsection{Chemical Properties}

$P^{H}$ : The $\mathrm{P}^{\mathrm{H}}$ of the rooting media was determined by meters, from a 1:2.5 soil-water suspension.

Organic carbon (\%): organic carbon content of the soil was determined by the wet combustion procedure of Walkley and Black method (1934).

Total nitrogen (\%): Total nitrogen content of the rooting media was determined by wet-oxidation procedure using modified Kjeldahl method.

Available phosphorus (ppm): The available phosphorus content of the rooting media was determined by $0.5 \mathrm{M}$ sodium bicarbonate extraction solution (PH 8.5) method of Olsen(1954)

Available potassium (ppm): The available potassium content of the rooting media was determined by using atomic absorption or flame photometer.

\subsection{Dry Matter Parameter}

Root dry weight (g): after drying the root in an oven drier (at a temperature of $100{ }^{\circ} \mathrm{C}$ to constant weight) weight was measured using a sensitive balance and the average was calculated for each treatment.

Root to shoot dry weight ratio: root to shoot dry weight ratio was determined by dividing dry weight of root to shoot of each sample cuttings and the average was calculated for each treatment.

Shoot dry weight (g): after drying the shoots in an oven drier (at a temperature of $100{ }^{\circ} \mathrm{C}$ to constant weight) weight was measured using a sensitive balance and the average was calculated for each treatment.

\subsection{Data Analysis}

Data collected for various root and shoot, dry matter parameters were checked for meeting the assumption for ANOVA. The results were presented for discussion per plant basis. The percentage data (percentage of sprouting) was transformed using the Arc sign transformation method before analysis. Data were analyzed using SAS software (SAS version 9.2, 2008). Mean comparison were perform using the Duncan's Multiple Range Test (DMRT) method. A significant level of 5\% used for all statistical analysis.

Linear statistical model for split-split-plot design

- $\quad y_{\mathrm{ijkh}}=\mu+\mathrm{A}_{\mathrm{i}}+\beta_{\mathrm{j}}+\mathrm{d}_{\mathrm{ijj}}+\mathrm{B}_{\mathrm{k}}+(\mathrm{AB})_{\mathrm{ik}}+\mathrm{f}_{\mathrm{ijk}}+\mathrm{C}_{\mathrm{h}}+(\mathrm{AC})_{\mathrm{ih}}+(\mathrm{BC})_{\mathrm{kh}}+(\mathrm{ABC})_{\mathrm{ikh}}+\varepsilon_{\mathrm{ijkh}}$

Where

$\mathrm{y}_{\mathrm{ijkh}=}$ The response measurement for the $i j k h^{\text {th }}$ observations

$\mu=$ the experiment mean

$A_{i}=$ the main plot treatment effect

$\beta_{j}=$ the block effect

$\operatorname{dij}=$ the main plot error (error a)

$B_{k}=$ the subplot treatment effect

$(A B)_{i k}=$ the treatment interaction effect

fijk $=$ the subplot error (error b)

$C_{h} \quad=$ the sub subplot treatment effect

$(A C)_{i h}=$ the treatment interaction effect

$(B C)_{k h}=$ the treatment interaction effect

$(A B C)_{i k h}=$ the treatment interaction effect

$\varepsilon_{i j k}=$ the sub subplot error (error $\mathrm{c}$ )

$\mathrm{i}, \mathrm{k}, \mathrm{h}=\mathrm{a}$ particular treatment

$\mathrm{j}=\mathrm{a}$ particular block 
Effect of Rooting Media, Cutting Types and Watering Frequency on Dry Matter Production of Long Pepper (Piper cappense) at Jimma

\section{RESUlTS AND Discussion}

\section{Dry Matter Production}

\subsection{Shoot Dry Weight (g)}

The analysis of variance for Average Dry shoot weight of long pepper stem cutting was significantly influenced by watering frequency, rooting media and cutting type. The main effect of watering frequency, rooting media, the interaction effect of watering frequency with rooting media, watering frequency with cutting type and media with cutting type, the three way interaction effect of watering frequency, rooting media and cutting type were very highly significant $(\mathrm{P}<0.001)$ difference. However, main effect of cutting types did not show significant $(\mathrm{p}>0.05)$ difference (Table 3$)$.

Table3. Analysis of variance for shoot dry weight $(g)$ per cutting of long pepper

\begin{tabular}{|c|c|c|c|c|c|c|}
\hline Source & DF & $\begin{array}{l}\text { Sum of } \\
\text { Squares }\end{array}$ & $\begin{array}{l}\text { Mean } \\
\text { Square }\end{array}$ & F-Ratio & p-Value & Significant \\
\hline rep & 2 & 18.5404 & 9.2702 & 2.0022 & 0.2157 & NS \\
\hline WF & 3 & 156.0141 & 52.0047 & 11.2318 & 0.0071 & $*$ \\
\hline Error(a) & 6 & 27.7807 & 4.6301 & . &. & \\
\hline MEDIA & 3 & 101.4830 & 33.8277 & 19.4169 & $<.0001$ & $*$ \\
\hline WF*MEDIA & 9 & 110.2573 & 12.2508 & 7.0319 & $<.0001$ & $*$ \\
\hline Error(b) & 24 & 41.8122 & 1.7422 & . & . & \\
\hline CUTTING & 2 & 4.1317 & 2.0658 & 0.8372 & 0.4376 & NS \\
\hline WF*CUTTING & 6 & 60.4678 & 10.0780 & 4.0841 & 0.0016 & $*$ \\
\hline MEDIA*CUTTING & 6 & 46.5156 & 7.7526 & 3.1417 & 0.0092 & $*$ \\
\hline WF*MEDIA*CUTTING & 18 & 230.2250 & 12.7903 & 5.1833 & $<.0001$ & $*$ \\
\hline Error(c) & 64 & 157.9267 & 2.4676 & 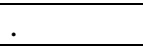 & . & \\
\hline Total & 143 & 955.1544 &. & . & . & \\
\hline
\end{tabular}

The highest average dry shoot weight per cutting (14.7g and $14.3 \mathrm{~g})$ was recorded under watering interval every week grown in (2ts: $1 \mathrm{fym}: 1 \mathrm{fs})$ media proportion, watering frequency every three weeks grown in the same rooting media and cutting type respectively (Table 6). The least average dry shoot weight per cutting $(5.33 \mathrm{~g}$ ) was recorded under semi hard wood cutting type grown under 2ts: 1 fym:1fs media proportion by watering interval every month.

\subsection{Root dry weight (g)}

The analysis of variance for Average dry root weight of long pepper stem cutting was significantly influenced by watering frequency, rooting media and cutting type. The analysis of variance has showed highly significant $(\mathrm{P}<0.001)$ difference among interaction effect of watering frequency with rooting media, media with cutting type and watering frequency, rooting media and cutting type. However not significant difference $(\mathrm{P}>0.05)$ was recorded on the main effect of watering frequency, rooting media and cutting type and the interaction effect of watering frequency by cutting type (Table 4).

Table4. Analysis of variance for dry root weight per cutting of long pepper

\begin{tabular}{|c|c|c|c|c|c|c|}
\hline Source & DF & $\begin{array}{l}\text { Sum of } \\
\text { Squares }\end{array}$ & \begin{tabular}{|l|} 
Mean \\
Square
\end{tabular} & F-Ratio & p-Value & Significant \\
\hline rep & 2 & 0.3537 & 0.1769 & 0.2593 & 0.7798 & $\mathrm{NS}$ \\
\hline WF & 3 & 9.0819 & 3.0273 & 4.4378 & 0.0574 & NS \\
\hline Error(a) & 6 & 4.0929 & 0.6822 & . & . & \\
\hline MEDIA & 3 & 0.8491 & 0.2830 & 2.6059 & 0.0751 & NS \\
\hline WF*MEDIA & 9 & 3.7517 & 0.4169 & 3.8381 & 0.0040 & $*$ \\
\hline Error(b) & 24 & 2.6067 & 0.1086 & . & . & \\
\hline CUTTING & 2 & 0.4467 & 0.2233 & 1.7896 & 0.1753 & NS \\
\hline WF*CUTTING & 6 & 1.2683 & 0.2114 & 1.6939 & 0.1369 & NS \\
\hline MEDIA*CUTTING & 6 & 2.3444 & 0.3907 & 3.1311 & 0.0094 & $*$ \\
\hline WF*MEDIA*CUTTING & 18 & 11.2272 & 0.6237 & 4.9982 & $<.0001$ & $*$ \\
\hline Error $(\mathrm{c})$ & 64 & 7.9867 & 0.1248 & . & . & \\
\hline Total & 143 & 44.0094 & . & . & . & \\
\hline
\end{tabular}


Effect of Rooting Media, Cutting Types and Watering Frequency on Dry Matter Production of Long Pepper (Piper cappense) at Jimma

The highest average dry root weight per cutting $(2.7 \mathrm{~g})$ was recorded under watering interval every two weeks, hard wood cutting types grown in 6TS: 3FYM: 2FS media proportion. Likewise with in interaction of media and cutting type the highest average dry root weight per cutting $(2.13 \mathrm{~g})$ was recorded under semi hard wood cutting type grown in (1/3 SS + 2TS: 1FYM:1FS) media proportion Table 6 . The least average root weight $(0.5 \mathrm{~g})$ was recorded for watering interval every month, soft wood cutting types, grown under (2TS: 1FYM:1FS ) media proportion Table 6.

\subsection{Root to Shoot Dry Weight Ratio}

Root to shoot ratio was highly significant $(\mathrm{p}<0.01)$ and was influenced by interaction effect of watering frequency, rooting media and cutting types. The main effect of rooting media and the interaction effect of watering frequency with rooting media, rooting media and cutting types and three-way interaction of watering frequency, rooting media and cutting types were highly significant. However, the main effect of cutting types and the interaction effect of watering frequency with cutting types showed no significant difference (Table 5).

Table5. Analysis of variance for root to shoot dry weight ratio per cutting of long pepper

\begin{tabular}{|c|c|c|c|c|c|c|}
\hline Source & DF & $\begin{array}{l}\text { Sum of } \\
\text { Squares }\end{array}$ & \begin{tabular}{|l|} 
Mean \\
Square
\end{tabular} & F-Ratio & p-Value & Significant \\
\hline rep & 2 & 0.0199 & 0.0100 & 1.8663 & 0.2343 & NS \\
\hline WF & 3 & 0.0500 & 0.0167 & 3.1197 & 0.1095 & NS \\
\hline Error(a) & 6 & 0.0320 & 0.0053 & . & . & \\
\hline MEDIA & 3 & 0.0215 & 0.0072 & 6.0804 & 0.0031 & $*$ \\
\hline WF*MEDIA & 9 & 0.0511 & 0.0057 & 4.8179 & 0.0010 & $*$ \\
\hline Error(b) & 24 & 0.0283 & 0.0012 & 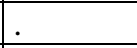 &. & \\
\hline CUTTING & 2 & 0.0051 & 0.0026 & 1.3826 & 0.2583 & NS \\
\hline WF*CUTTING & 6 & 0.0111 & 0.0018 & 0.9998 & 0.4333 & NS \\
\hline MEDIA*CUTTING & 6 & 0.0459 & 0.0077 & 4.1398 & 0.0014 & $*$ \\
\hline WF*MEDIA*CUTTING & 18 & 0.1657 & 0.0092 & 4.9790 & $<.0001$ & $*$ \\
\hline Error(c) & 64 & 0.1183 & 0.0018 &. & . & \\
\hline Total & 143 & 0.5489 & . &. &. & \\
\hline
\end{tabular}

The highest root to shoot ratio $(0.33 \%)$ was registered for watering frequency every three week and semi hard wood cutting type grown in (2TS: 1FYM:2FS) media proportion (Table 6). The least root to shoot ratio $(0.04 \%)$ was recorded for watering interval every week month, soft wood cutting grow in (2TS: 1FYM:1FS) media proportion (Table 6).

Table6. Interaction effect of watering frequency, rooting media and cutting types on various dry matter production of long pepper accessions

\begin{tabular}{|c|c|c|c|c|c|}
\hline $\begin{array}{l}\text { Watering } \\
\text { Frequency }\end{array}$ & Rooting media & $\begin{array}{l}\text { Cutting } \\
\text { type }\end{array}$ & $\begin{array}{l}\text { Sh dry } \\
\text { Wt.(g) }\end{array}$ & $\begin{array}{l}\text { R dry } \\
\text { wt. (g) }\end{array}$ & $\begin{array}{l}\mathrm{R} \text { to Sh Ratio } \\
\%\end{array}$ \\
\hline $\begin{array}{l}\text { Every } \\
\text { week }\end{array}$ & 2TS:1FYM:2FS & SW & $10.667^{e-j}$ & $1.8^{\mathrm{d}-\mathrm{h}}$ & $0.17^{\mathrm{c}-\mathrm{m}}$ \\
\hline $\begin{array}{l}\text { Every } \\
\text { week }\end{array}$ & 2TS:1FYM:2FS & SHW & $10.333^{\mathrm{f}-\mathrm{k}}$ & $1.9^{\mathrm{c}-\mathrm{h}}$ & $0.18^{\mathrm{c}-\mathrm{m}}$ \\
\hline $\begin{array}{l}\text { Every } \\
\text { week }\end{array}$ & 2TS:1FYM:2FS & HW & $8^{k-n}$ & $1.2^{\mathrm{ijk}}$ & $0.16^{\mathrm{e}-\mathrm{m}}$ \\
\hline $\begin{array}{l}\text { Every } \\
\text { week }\end{array}$ & 6TS:3FYM:2FS & SW & $9.333^{\mathrm{h}-\mathrm{m}}$ & $1.36^{\mathrm{h}-\mathrm{k}}$ & $0.15^{\mathrm{f}-\mathrm{m}}$ \\
\hline $\begin{array}{l}\text { Every } \\
\text { week }\end{array}$ & 6TS:3FYM:2FS & SHW & $12.333^{\mathrm{a}-\mathrm{g}}$ & $1.73^{\mathrm{e}-\mathrm{i}}$ & $0.14^{\mathrm{l}-\mathrm{m}}$ \\
\hline $\begin{array}{l}\text { Every } \\
\text { week }\end{array}$ & 6TS:3FYM:2FS & HW & $11.333^{\mathrm{c}-\mathrm{i}}$ & $1.73^{\mathrm{e}-\mathrm{i}}$ & $0.16^{\mathrm{e}-\mathrm{m}}$ \\
\hline $\begin{array}{l}\text { Every } \\
\text { week }\end{array}$ & 1/3 SS+2TS:1FYM:1FS & SW & $8.667^{\mathrm{j}-\mathrm{m}}$ & $1.56^{g-j}$ & $0.18^{\mathrm{c}-\mathrm{m}}$ \\
\hline $\begin{array}{l}\text { Every } \\
\text { week }\end{array}$ & 1/3 SS+2TS:1FYM:1FS & SHW & $10.667^{\mathrm{e}-\mathrm{j}}$ & $1.73^{\mathrm{e}-\mathrm{i}}$ & $0.16^{\mathrm{d}-\mathrm{m}}$ \\
\hline $\begin{array}{l}\text { Every } \\
\text { week }\end{array}$ & 1/3 SS+2TS:1FYM:1FS & HW & $11.333^{\mathrm{c}-\mathrm{i}}$ & $1.6^{g-j}$ & $0.15^{\mathrm{g}-\mathrm{m}}$ \\
\hline
\end{tabular}


Effect of Rooting Media, Cutting Types and Watering Frequency on Dry Matter Production of Long Pepper (Piper cappense) at Jimma

\begin{tabular}{|c|c|c|c|c|c|}
\hline $\begin{array}{l}\text { Every } \\
\text { week }\end{array}$ & 2TS:1FYM:1FS & SW & $14.667^{\mathrm{a}}$ & $1.8^{\mathrm{d}-\mathrm{h}}$ & $0.12^{\mathrm{k}-\mathrm{m}}$ \\
\hline $\begin{array}{l}\text { Every } \\
\text { week }\end{array}$ & 2TS:1FYM:1FS & SHW & $10.333^{\mathrm{f}-\mathrm{k}}$ & $1.4^{\mathrm{h}-\mathrm{k}}$ & $0.14^{\mathrm{l}-\mathrm{m}}$ \\
\hline $\begin{array}{l}\text { Every } \\
\text { week }\end{array}$ & 2TS:1FYM:1FS & HW & $10^{g-1}$ & $1.65^{e-j}$ & $0.16^{\mathrm{e}-\mathrm{m}}$ \\
\hline $\begin{array}{ll}\text { Every two } \\
\text { week }\end{array}$ & 2TS:1FYM:2FS & SW & $11.667^{\mathrm{b}-\mathrm{h}}$ & $1.31^{\mathrm{h}-\mathrm{k}}$ & $0.14^{1-m}$ \\
\hline $\begin{array}{ll}\text { Every } & \text { two } \\
\text { week } & \\
\end{array}$ & 2TS:1FYM:2FS & SHW & $10^{\mathrm{g}-1}$ & $1.56^{\mathrm{g}-\mathrm{j}}$ & $0.16^{\mathrm{e}-\mathrm{m}}$ \\
\hline $\begin{array}{ll}\text { Every } & \text { two } \\
\text { week } & \\
\end{array}$ & 2TS:1FYM:2FS & HW & $13.667 \mathrm{abc}$ & $2.46^{\mathrm{abc}}$ & $0.18^{\mathrm{c}-\mathrm{m}}$ \\
\hline $\begin{array}{ll}\text { Every } & \text { two } \\
\text { week } & \end{array}$ & 6TS:3FYM:2FS & SW & $10^{g-1}$ & $1.9^{\mathrm{c}-\mathrm{h}}$ & $0.19^{\mathrm{b}-\mathrm{k}}$ \\
\hline $\begin{array}{ll}\text { Every two } \\
\text { week }\end{array}$ & 6TS:3FYM:2FS & SHW & $11.667^{\mathrm{b}-\mathrm{h}}$ & $1.73^{\mathrm{e}-\mathrm{i}}$ & $0.15^{\mathrm{g}-\mathrm{m}}$ \\
\hline $\begin{array}{ll}\text { Every two } \\
\text { week }\end{array}$ & 6TS:3FYM:2FS & HW & $11^{\mathrm{d}-\mathrm{j}}$ & $2.7^{\mathrm{a}}$ & $0.24^{\mathrm{b}-\mathrm{d}}$ \\
\hline $\begin{array}{ll}\text { Every } & \text { two } \\
\text { week } & \\
\end{array}$ & 1/3 SS+2TS:1FYM:1FS & SW & $14^{\mathrm{ab}}$ & $1.46^{\mathrm{h}-\mathrm{k}}$ & $0.11 \mathrm{mn}$ \\
\hline $\begin{array}{ll}\text { Every } & \text { two } \\
\text { week } & \end{array}$ & 1/3 SS+2TS:1FYM:1FS & SHW & $10^{g-1}$ & $2.2^{\mathrm{a}-\mathrm{f}}$ & 0.22 b-f \\
\hline $\begin{array}{l}\text { Every two } \\
\text { week }\end{array}$ & 1/3 SS+2TS:1FYM:1FS & HW & $13.333^{\mathrm{a}-\mathrm{d}}$ & $1.86^{\mathrm{d}-\mathrm{h}}$ & $0.14^{\mathrm{h}-\mathrm{m}}$ \\
\hline $\begin{array}{ll}\text { Every } & \text { two } \\
\text { week } & \\
\end{array}$ & 2TS:1FYM:1FS & SW & $10^{\mathrm{g}-1}$ & $2.6^{\mathrm{ab}}$ & $0.27^{\mathrm{ab}}$ \\
\hline $\begin{array}{ll}\text { Every two } \\
\text { week }\end{array}$ & 2TS:1FYM:1FS & SHW & $11^{\mathrm{d}-\mathrm{j}}$ & $1.73^{\mathrm{e}-\mathrm{i}}$ & $0.15^{\mathrm{f}-\mathrm{m}}$ \\
\hline $\begin{array}{ll}\text { Every } & \text { two } \\
\text { week } & \end{array}$ & 2TS:1FYM:1FS & HW & $13^{\mathrm{a}-\mathrm{e}}$ & $1.56^{\mathrm{g}-\mathrm{j}}$ & $0.12^{\mathrm{lm}}$ \\
\hline $\begin{array}{l}\text { Every } \\
\text { three week }\end{array}$ & 2TS:1FYM:2FS & SW & $9^{\mathrm{i}-\mathrm{m}}$ & $2.06^{b-g}$ & 0.24 bcd \\
\hline $\begin{array}{l}\text { Every } \\
\text { three week }\end{array}$ & 2TS:1FYM:2FS & SHW & 7 mno & $2.26^{\mathrm{a}-\mathrm{e}}$ & $0.33^{\mathrm{a}}$ \\
\hline $\begin{array}{l}\text { Every } \\
\text { three week }\end{array}$ & 2TS:1FYM:2FS & HW & $6^{\text {no }}$ & $1.36^{\mathrm{h}-\mathrm{k}}$ & 0.23 b-e \\
\hline $\begin{array}{l}\text { Every } \\
\text { three week }\end{array}$ & 6TS:3FYM:2FS & SW & $11.333^{\mathrm{c}-\mathrm{i}}$ & $2.23^{\mathrm{a}-\mathrm{e}}$ & $0.19^{\mathrm{c}-1}$ \\
\hline $\begin{array}{l}\text { Every } \\
\text { three week }\end{array}$ & 6TS:3FYM:2FS & SHW & $10.333^{\mathrm{f}-\mathrm{k}}$ & $1.63^{f-j}$ & $0.17^{\mathrm{c}-\mathrm{m}}$ \\
\hline $\begin{array}{l}\text { Every } \\
\text { three week }\end{array}$ & 6TS:3FYM:2FS & HW & $9^{\mathrm{i}-\mathrm{m}}$ & $2.26^{\mathrm{a}-\mathrm{e}}$ & $0.26^{\mathrm{ab}}$ \\
\hline $\begin{array}{l}\text { Every } \\
\text { three week }\end{array}$ & 1/3 SS+2TS:1FYM:1FS & SW & $9.333^{\mathrm{h}-\mathrm{m}}$ & $1.83^{\mathrm{d}-\mathrm{h}}$ & $0.20^{\mathrm{b}-\mathrm{j}}$ \\
\hline $\begin{array}{l}\text { Every } \\
\text { three week }\end{array}$ & 1/3 SS+2TS:1FYM:1FS & SHW & $13^{\mathrm{a}-\mathrm{e}}$ & $2.3^{\mathrm{a}-\mathrm{e}}$ & $0.18^{\mathrm{c}-\mathrm{m}}$ \\
\hline $\begin{array}{l}\text { Every } \\
\text { three week }\end{array}$ & 1/3 SS+2TS:1FYM:1FS & HW & $12.667^{\mathrm{a}-\mathrm{f}}$ & $2.26^{\mathrm{a}-\mathrm{e}}$ & $0.18^{\mathrm{c}-\mathrm{m}}$ \\
\hline $\begin{array}{l}\text { Every } \\
\text { three week }\end{array}$ & 2TS:1FYM:1FS & SW & $14.333^{\mathrm{a}}$ & $1.53^{\mathrm{g}-\mathrm{j}}$ & $0.13^{\mathrm{j}-\mathrm{m}}$ \\
\hline $\begin{array}{l}\text { Every } \\
\text { three week }\end{array}$ & 2TS:1FYM:1FS & SHW & $12.333^{\mathrm{a}-\mathrm{g}}$ & $2.56^{\mathrm{ab}}$ & $0.18^{\mathrm{c}-1}$ \\
\hline $\begin{array}{l}\text { Every } \\
\text { three week }\end{array}$ & 2TS:1FYM:1FS & HW & $12.333^{\mathrm{a}-\mathrm{g}}$ & $2.36^{\mathrm{a}-\mathrm{d}}$ & $0.19^{\mathrm{b}-\mathrm{k}}$ \\
\hline $\begin{array}{l}\text { Every Four } \\
\text { Weeks }\end{array}$ & 2TS:1FYM:2FS & SW & $6^{\text {no }}$ & $1.16^{\mathrm{ijk}}$ & $0.21^{\mathrm{b}-\mathrm{i}}$ \\
\hline $\begin{array}{l}\text { Every Four } \\
\text { Weeks }\end{array}$ & 2TS:1FYM:2FS & SHW & $9^{\mathrm{i}-\mathrm{m}}$ & $1.4^{\mathrm{h}-\mathrm{k}}$ & $0.15^{\mathrm{f}-\mathrm{m}}$ \\
\hline $\begin{array}{l}\text { Every Four } \\
\text { Weeks }\end{array}$ & 2TS:1FYM:2FS & HW & $8.667^{\mathrm{j}-\mathrm{m}}$ & $1.73^{\mathrm{e}-\mathrm{i}}$ & $0.22^{\mathrm{b}-\mathrm{h}}$ \\
\hline Every Four & 6TS:3FYM:2FS & SW & $10^{\mathrm{g}-1}$ & $1.53^{\mathrm{g}-\mathrm{j}}$ & $0.17^{\mathrm{c}-\mathrm{m}}$ \\
\hline
\end{tabular}


Effect of Rooting Media, Cutting Types and Watering Frequency on Dry Matter Production of Long Pepper (Piper cappense) at Jimma

\begin{tabular}{|c|c|c|c|c|c|}
\hline Weeks & & & & & \\
\hline $\begin{array}{l}\text { Every Four } \\
\text { Weeks }\end{array}$ & 6TS:3FYM:2FS & SHW & $7.667^{1-o}$ & $0.93^{\mathrm{kl}}$ & $0.14^{1-m}$ \\
\hline $\begin{array}{l}\text { Every Four } \\
\text { Weeks }\end{array}$ & 6TS:3FYM:2FS & HW & $8^{k-n}$ & $1.33^{\mathrm{h}-\mathrm{k}}$ & $0.18^{\mathrm{c}-1}$ \\
\hline $\begin{array}{l}\text { Every Four } \\
\text { Weeks }\end{array}$ & 1/3 SS+2TS:1FYM:1FS & SW & $9.667^{\text {h-l }}$ & $2.06^{b-g}$ & $0.22^{b-g}$ \\
\hline $\begin{array}{l}\text { Every Four } \\
\text { Weeks }\end{array}$ & 1/3 SS+2TS:1FYM:1FS & SHW & $9.333^{\mathrm{h}-\mathrm{m}}$ & $2.26^{\mathrm{a}-\mathrm{e}}$ & $0.24 \mathrm{bc}$ \\
\hline $\begin{array}{l}\text { Every Four } \\
\text { Weeks }\end{array}$ & 1/3 SS+2TS:1FYM:1FS & HW & $10.667^{e-j}$ & $1.53^{\mathrm{g}-\mathrm{j}}$ & $0.14^{\text {h-n }}$ \\
\hline $\begin{array}{l}\text { Every Four } \\
\text { Weeks }\end{array}$ & 2TS:1FYM:1FS & SW & $13^{\mathrm{a}-\mathrm{e}}$ & $0.5^{1}$ & $0.04^{n}$ \\
\hline $\begin{array}{l}\text { Every Four } \\
\text { Weeks }\end{array}$ & 2TS:1FYM:1FS & SHW & $5.333^{\circ}$ & $1.13^{\mathrm{jk}}$ & $0.27^{\mathrm{ab}}$ \\
\hline $\begin{array}{l}\text { Every Four } \\
\text { Weeks }\end{array}$ & 2TS:1FYM:1FS & HW & $9.333^{\mathrm{h}-\mathrm{m}}$ & $1.6^{g-j}$ & $0.19^{\mathrm{c}-1}$ \\
\hline C.V \% & & & 15.14 & 20.02 & 24.12 \\
\hline $\begin{array}{l}\text { LSD } 0.05 \\
\text { \%level }\end{array}$ & & & 2.54 & 0.64 & 0.07 \\
\hline
\end{tabular}

Sh dry Wt. =Shoot Dry Weight (g), R dry wt. =Root dry weight (g), R to sh Ratio $=$ Root to Shoot Ratio

\section{SUMMARY AND CONCLUSION}

The results of the present investigation suggested that the rooting and shoot growth of leafless hard wood cuttings of long pepper (piper cappense) is related to all the factors studied: rooting media, cutting type and watering frequency of the stock plant at the time of taking cuttings. In this experiment, cutting type significantly affected average dry shoot weight and root to shoot ratio of long pepper cutting. Cuttings obtained from the soft wood cutting type showed greater performance regarding average shoot dry weight considered, as compared to those cuttings collected from semi hard and hard wood portions of the stock plant. In general, soft wood cuttings gave rise to the best and well developed long pepper seedlings. The current result had also revealed the need for considering; watering interval was significantly affected average dry shoot weight of long pepper cutting. Watering interval every two week and every week showed greater performance regarding all dry matter parameters considered that for good seedling growth.

\section{REFERENCES}

[1] Behailu Atero, Gibramu Temesgen and Bayetta Belachew. 2006. Effect of type of cutting and media mixture on rooting ability on Arabica coffee hybrid. In proceeding of the eleventh conference Crop Science Society of Ethiopia,pp135-138. Addis Ababa, Ethiopia.

[2] Sahlemedhin Sertsu and Taye Bekele, 2000. Procrdures for soil and plant anlysis. National Soil Research Centre, Ethiopian Agricultural Research Organization, Addis Ababa, Ethiopia. 110p.

[3] Olsen, S. R., Cole, C. V., Watanabe, F. S. \& Dean. L. A. (1954). Estimation of available phosphorus in soils by extraction with NaHCO3, USDA Cir.939. U.S. Washington.

[4] Walkley, A.J. and Black, I.A. (1934) Estimation of soil organic carbon by the chromic acid titration method. Soil Sci. 37, 29-38.

Citation: Mohammedsani Zakir, et.al.," Effect of Rooting Media, Cutting Types and Watering Frequency on Dry Matter Production of Long Pepper (Piper cappense) at Jimma".. International Journal of Research Studies in Agricultural Sciences (IJRSAS), 2021; 7(4), pp. 19-26, https://doi.org/10.20431/2454-6224.0704003.

Copyright: () 2021 Authors. This is an open-access article distributed under the terms of the Creative Commons Attribution License, which permits unrestricted use, distribution, and reproduction in any medium, provided the original author and source are credited. 